\title{
Extraction and characterisation of cassava starch cultivated in different locations in Sabah, Malaysia
}

\author{
1,*Hasmadi, M., ${ }^{1}$ Harlina, L., ${ }^{1}$ Jau-Shya, Lee, ${ }^{1}$ Mansoor, A.H., ${ }^{1}$ Jahurul, M.H A. and \\ ${ }^{2}$ Zainol, M.K.
}

${ }^{1}$ Food Technology and Bioprocessing Program, Faculty of Food Science and Nutrition, Universiti Malaysia Sabah, 88400 Kota Kinabalu, Sabah, Malaysia

${ }^{2}$ Faculty of Fisheries and Food Sciences, Universiti Malaysia Terengganu, 21030, Kuala Nerus, Terengganu, Malaysia

\begin{abstract}
Article history:
Received: 29 September 2020 Received in revised form: 16 November 2020

Accepted: 21 January 2021 Available Online: 2 May 2021
\end{abstract}

\section{Keywords:}

Cassava starch,

Amylose/amylopectin,

Functional properties,

Pasting properties,

Gelatinisation,

Retrogradation

DOI:

https://doi.org/10.26656/fr.2017.5(3).550

\begin{abstract}
This work aimed to determine the physicochemical and functional properties of starch cassava grown in two different locations in Sabah, namely Tawau and Semporna. In this study, the starch of the cassava was extracted using a wet method and analysed for its physicochemical and functional properties. The total starch content of cassava grown in Semporna showed a higher value $(61.21 \mathrm{~g} / 100 \mathrm{~g})$ compared to the sample from Tawau $(51.77 \mathrm{~g} / 100 \mathrm{~g})$. No significant difference $(\mathrm{p}>0.05)$ observed for starch yield extracted from these two locations. However, there was a significant difference $(p<0.05)$ showed for total starch, resistant starch and amylose content. The amylose content of starch isolated from Semporna $(23.16 \%)$ was higher than from Tawau (13.87\%). Scanning electron microscope revealed that starch isolated from both locations had smooth surfaces with some granules spherical, elongated and irregular in shape. Cassava starch from Semporna exhibited a high value of swelling power (6.85\%) compared to Tawau (4.07\%), and they were significantly different $(\mathrm{p}<0.05)$. The solubility values of the starch samples from Tawau and Semporna were $28.48 \%$ and $24.34 \%$, respectively. The $\mathrm{pH}$ was observed to be lower for cassava starch isolated from Tawau (4.80) than for starch obtained from Semporna (5.49). The water absorption capacity of starch from Semporna absorbed slightly more water than starch from Tawau, with values of $76.51 \%$ and $63.64 \%$, respectively. Pasting properties results showed no significance for all profiles measured except for setback viscosity. No significant differences $(p>0.05)$ were observed for all gelatinisation and retrogradation properties. This study suggests that location influenced the physical, chemical and functional properties of cassava's starch.
\end{abstract}

\section{Introduction}

Cassava (Manihot esculenta, Crantz) is one of the most important root crops in tropical countries that providing energy to human due to a significant amount of carbohydrates and high nutritional value in its roots. Typical mature roots have an average composition of 60 $-70 \%$ moisture, $30-35 \%$ carbohydrate, $1-2 \%$ fat, $1-2 \%$ fibre and $1-2 \%$ protein, with trace quantities of vitamins and minerals. Mature roots can range in starch content from as low as $15 \%$ to as high as $33 \%$, depending on the climate and harvest time (Breuninger et al., 2009).

Starch is one of the most important functional food biopolymers (Mamat and Hill, 2018). It is one of the main components in cassava that have been utilised in food industries to facilitate the processing method as well as improved final food products. The starch content of the fresh cassava root is about $30 \%$ and gives the highest yield of starch per unit area of any crop known (Tanukari, 2004). It's a complex carbohydrate and among the most abundant of plant products, a major food reserve providing nutrient and energy source.

Starch is the most consumed carbohydrates in the human diet. It is deposited in the fruit in the form of granules, partially crystalline, whose morphology, chemical composition, and supermolecular structure are characteristic of each particular plant species. Starch owes much of its functionality to two major high molecular weight carbohydrate components, amylose and amylopectin, as well as to the physical organisation of these macromolecules into the granular structure 
(French, 1984). Amylose is a linear polymer consisting of $\alpha$-D-glucopyranose residues are linked through $\alpha$ $(1 \rightarrow 4)$ glycosidic bonds whereas amylopectin is a branched polymer with $\alpha-(1 \rightarrow 4)$ glycosidic bonds, having periodic branches at the O-6 position (Buléon et al., 1998)

Asoaka et al. (1991) studied the effect of cultivar and seasonal towards physicochemical properties of cassava starch. They found that even though there are differences in organoleptic properties of cooked cassava root, yet, there is only a minor difference in physicochemical properties of starch granules. Tester et al. (1997) reported that high temperature would give an effect on the biosynthesis process in cassava starch causes depressed starch deposition to lead to low yield of starch because the synthesis of starch granules is small and little.

Functional and pasting properties of cassava flour and starch are important in the food industry since they will directly affect food products (Niba et al., 2002; Mishra and Rai, 2006; Hasmadi et al., 2020). However, the study on the characterisation of cassava flour in Malaysia, especially in Sabah, is scarce. Therefore, the objective of this study is to determine the physicochemical and functional properties of cassava starch extracted from two different districts in Sabah, namely Tawau and Semporna.

\section{Materials and methods}

\subsection{Raw materials}

The matured white variety of cassava (9 months of age) was harvested from Tawau and Semporna, Sabah, Malaysia.

\subsection{Starch extraction and yield}

Extraction of cassava starch was conducted using the wet method as described by Noorfarahzilah et al. (2020) with slight modifications. Cassava was mixed with water in a ratio of 1:10 and blended at high speed until smooth slurry formed. After blending, filtration of the slurry was done using a double layer of cheesecloth. The filtered mixture then was allowed to rest for two hrs to help the sedimentation process of starch and liquid at the top was decanted and discarded. The sediment then undergoes a drying process at $45^{\circ} \mathrm{C}$ for $24 \mathrm{hrs}$ and stored in an airtight container for further analysis. Percentage of extraction yield was calculated using the formula as follow:

$$
\text { Extraction Yield }(\%)=\frac{\text { Starch weight }(g)}{\text { Cassava weight }(g)} \times 100
$$

\subsection{Determination of total starch content}

Total starch content was determined using a kit assay (Megazyme International, Wicklow, Ireland) based on the AOAC method 996.1 (2000) by enzymatic hydrolysis of starch using amylase/amyloglucosidases and quantification of glucose using glucose oxidase/ peroxidase reagent.

\subsection{Determination of amylose/amylopectin content}

The amylose content was determined using an amylose/amylopectin assay kit (Megazyme International, Wicklow, Ireland) by selective quantitative precipitation of amylopectin with concanavalin A (Con A) and removing it by centrifugation.

\subsection{Determination of resistance starch}

Resistant starch was determined using a kit assay (Megazyme International, Wicklow, Ireland). This kit follows the protocols of the AOAC method 2002.02 (2000) procedures described by Niba and Hoffman (2003).

\subsection{Determination of water absorption capacity}

The water absorption capacity of samples was determined according to the method described by Mustapha et al. (2015). The water absorption capacity of samples was then calculated by using a formula as follow:

$$
\text { Water absorption capacity }=\frac{W^{2}-W^{1}}{W^{0}}
$$

Where, $\mathrm{W}^{\mathrm{O}}=$ Sample weight $(\mathrm{g}), \mathrm{W}^{1}=$ Tube weight $(\mathrm{g})+$ sample weight $(\mathrm{g}), \mathrm{W}^{2}=$ Tube weight $(\mathrm{g})+$ sediment $(\mathrm{g})$.

\subsection{Determination of swelling power and solubility}

Swelling power and solubility was determined by the method described by Ikegwu et al. (2010) with a slight modification. The supernatant after the centrifugation process was poured into an aluminium plate and dried using an oven at $100 \pm 5^{\circ} \mathrm{C}$ for $4 \mathrm{hrs}$. The weight of the aluminium plate was taken every four hrs until there are no weight changes recorded. Properties of swelling power and solubility are then calculated based on the equation as follow:

$$
\begin{gathered}
\text { Solubility }(\%)=\frac{\text { weight of dried supernatant }}{\text { Sample weight }} \\
\text { Swelling Power }(\%)=\frac{W^{2}-W^{1}}{W^{0}}
\end{gathered}
$$

Where, $\mathrm{W}^{0}=$ Sample weight $(\mathrm{g}), \mathrm{W}^{1}=$ Sample weight $(\mathrm{g})+$ test tube weight $(\mathrm{g}), \mathrm{W}^{2}=$ Weight of swelled sediment $(\mathrm{g})+$ test tube weight $(\mathrm{g})$ 


\subsection{Determination of $p H$}

The $\mathrm{pH}$ of the cassava starch was determined by using $\mathrm{pH}$-meter based on the method described by Eriksson (2013).

\subsection{Determination of pasting properties}

The pasting properties were studied by using Rapid Visco Analyzer (RVA) as described by Chandanasree et al. (2016). Pasting profile recorded as peak viscosity, trough viscosity, breakdown viscosity, final viscosity, setback viscosity, pasting temperature and peak time.

\subsection{Determination of gelatinisation properties}

Gelatinisation properties were determined by using Differential Scanning Calorimeter (DSC) based on the method described by Mamat et al. (2010). Several parameters, such as onset temperature $\left(T_{o}\right)$, peak temperature $\left(T_{p}\right)$, end temperature $\left(T_{c}\right)$ and gelatinisation enthalpy $(\Delta H)$ were calculated and recorded.

\subsection{Determination of retrogradation properties}

Retrogradation properties were determined by using Differential Scanning Calorimeter (DSC) based on the method described by Raphael et al. (2011) with several modifications. The time used to allow retrogradation to occur completely was extended until 21 days. Several parameters, such as onset temperature $\left(T_{o}\right)$, peak temperature $\left(T_{p}\right)$, end temperature $\left(T_{c}\right)$ and retrogradation enthalpy $(\Delta H)$ was calculated and recorded.

\subsection{Determination of starch granule morphology}

The starch granule morphology was observed by using a Scanning Electron Microscope (SEM) based on the method as described by Chandanasree et al. (2016).

\subsection{Statistical analysis}

The values reported are the mean of three replicates. The significance of differences $(p<0.05)$ was assessed using an independent t-test performed by SPSS software.

\section{Results and discussion}

\subsection{Starch yield}

Starch yield is the amount of starch physically recoverable from cassava root. Starch yield for cassava starch from two different locations is given in Table 1. It was observed that cassava grown in Semporna exhibited a high extraction yield compared to cassava starch grown in Tawau with values of $22.58 \%$ and $21.71 \%$ respectively. However, statistical analysis showed that there was no significant difference $(p>0.05)$ in the percentage of extraction yield obtained from both locations. Zhu (2015) reported extraction yield of starch from cassava is varies depending on the method of extraction used and the area of cassava planted in which extraction can be as high as $80 \%$ and as low as $11 \%$. Various artificial factors affecting the starch yield include the drying conditions of raw materials, harvesting time and root storage, the status of the roots used for extraction and the environmental conditions for growing the crop ( $\mathrm{Zhu}, 2015)$. The results recorded in agreement with the findings reported by Abera and Rakashit (2003) and Joseph et al. (2004). However, Olomo and Ajibola (2003) reported a higher percentage of starch extraction, ranged from $48.8 \%$ to $79.9 \%$.

Table 1. Extraction yield, total starch content, amylose/ amylopectin content of cassava starch

\begin{tabular}{lcc}
\hline \multicolumn{1}{c}{ Analysis } & Tawau & Semporna \\
\hline Extraction yield (\%) & $21.71 \pm 0.50^{\mathrm{a}}$ & $22.58 \pm 1.48^{\mathrm{a}}$ \\
Total starch (g/100 g) & $51.77 \pm 0.07^{\mathrm{b}}$ & $61.21 \pm 0.17^{\mathrm{a}}$ \\
Amylose $(\%, \mathrm{w} / \mathrm{w})$ & $13.87 \pm 0.05^{\mathrm{b}}$ & $23.16 \pm 0.52^{\mathrm{a}}$ \\
Amylopectin $(\%, \mathrm{w} / \mathrm{w})$ & $85.44 \pm 1.10^{\mathrm{a}}$ & $74.28 \pm 0.12^{\mathrm{b}}$ \\
\hline
\end{tabular}

Values are expressed as mean \pm SD. Values with different superscript within the row are significantly different $(\mathrm{p}<0.05)$.

\subsection{Total starch}

The total starch content of cassava grown in Semporna showed a high value $(61.21 \mathrm{~g} / 100 \mathrm{~g})$ compared to the sample obtained from Tawau (51.77 $\mathrm{g} / 100 \mathrm{~g}$ ), as shown in Table 2. Results obtained are higher than values reported by Charles et al. (2004) (34.2 to $35.1 \%$ ) but lower than the finding reported by Aprianita et al. (2014) (77.4\%). Cassava is one of the four most important sources of starch worldwide, together with rice, maise and wheat. Niba et al. (2002) recorded starch content of flour from $62.8 \pm 1.13$ to $75.7 \pm 0.01 \mathrm{~g} / 100 \mathrm{~g}$ dry weight for eleven cassava root genotypes in Nigeria. Aniedu and Omodamiro (2012) analysed six newly bred $\beta$-carotene cassava and found that starch contents of the flours produced from the roots ranged from 23.18 to $61.05 \%$, which in agreement with our findings.

Table 2. Swelling power, solubility, $\mathrm{pH}$, water absorption capacity, resistance starch of cassava starch

\begin{tabular}{lcc}
\hline \multicolumn{1}{c}{ Analysis } & Tawau & Semporna \\
\hline Swelling power (\%) & $4.07 \pm 1.65^{\mathrm{b}}$ & $6.85 \pm 0.34^{\mathrm{a}}$ \\
Solubility (\%) & $28.48 \pm 1.13^{\mathrm{a}}$ & $24.34 \pm 4.91^{\mathrm{b}}$ \\
$\mathrm{pH}$ & $4.71 \pm 0.21^{\mathrm{b}}$ & $5.49 \pm 0.03^{\mathrm{a}}$ \\
Water absorption capacity $(\mathrm{mL} / \mathrm{g})$ & $63.64 \pm 3.58^{\mathrm{b}}$ & $76.51 \pm 0.11^{\mathrm{a}}$ \\
Resistant starch (g/100 g, dwb) & $6.99 \pm 0.28^{\mathrm{a}}$ & $4.65 \pm 1.04^{\mathrm{b}}$ \\
\hline
\end{tabular}

Values are expressed as mean \pm SD. Values with different superscript within the row are significantly different $(\mathrm{p}<0.05)$. 


\subsection{Amylose/amylopectin content}

Amylose and amylopectin composition play essential roles in cassava starch, influencing thermal properties such as gelatinisation, retrogradation, gelling, pasting as well as crystallinity (Blazek and Copeland, 2008). In this study, a significant difference $(\mathrm{p}<0.05)$ was observed for amylose content recorded for Semporna and Tawau with values of $23.16 \%$ and $13.87 \%$ (Table 1), respectively. Similar observations have been reported earlier (Mbougueng et al., 2009). Also, Li et al. (2001) and Charles et al. (2004) reported that the amylose content of cassava growth in Thailand falls ranged between $18 \%$ until $25 \%$. Amylopectin content of cassava flour from Semporna was higher (85\%) compared to Tawau (74\%) (Table 1).

Amylose and amylopectin content is important as it determines the functional properties of cassava starch. Cassava with low amylose content (as exhibit by cassava grown in Tawau), will decrease the amorphous region between starch granules thus lead to the increase in crystallinity properties (Tukomane et al., 2007). Furthermore, amylose content is one of the factors that influence the retrogradation properties of cassava starch in which high amylose content causes the ability of starch to retrograde increase due to the aggregation process of amylose that acts as the nucleus (RodriguezSandoval et al., 2008). Amylose content also influenced the pasting properties of starch. A high amount of amylose content will increase the pasting temperature because the releasing of amylose from the amylopectin network will be longer during gelatinisation, thus higher temperature required to form a starch paste (Moorthy, 2002).

\subsection{Resistant starch}

Resistant starch is defined as the fraction of starch that is resistant to digestion by $\alpha$-amylase and pullulanase enzymes in vitro and may be fermented in the colon (Ashwar et al., 2015). The results show that there were significant differences $(p<0.05)$ in the resistant starch content of the starch extracted from both locations (Table 2). The values recorded in this study are lower than reported in past research (Martín Bernabé et al., 2011). Resistant starch is indigestible by body enzymes and divided into 4 fractions namely RS1, RS2, RS3, and RS4 or also called type I, II, III, and IV starches (Sajilata et al., 2006). Most of the cassava starch is categorised as resistant starch type II (RS2) where starch is in a specific granular form and resistant to enzyme digestion. It is measured chemically as the difference between the glucose released by the enzyme digestion of a boiled homogenised food sample and that from an unboiled, non-homogenized food sample. In raw starch granules, starch is tightly packed in a radial pattern and is relatively dehydrated (Sajilata et al., 2006). Resistant starch gives several benefits to human health (Ashwar et al., 2015). Apart from providing benefits to human, resistance starch as well contributes to the quality of the final product in food such as crunchiness, mouth-feel and palatability (Buttriss and Stokes, 2008).

\subsection{Water absorption capacity}

From the results (Table 2), it was observed that starch from Semporna held slightly more water than starch from Tawau, with values of $76.51 \%$ and $63.64 \%$, respectively. Significant differences in the water absorption capacity were observed in this study. The protein content is one of the factors that influenced water absorption capacity in starch (Abdalla et al., 2009). Protein molecules trap and form a bond with water molecule through hydrogen bonding and electrostatic attraction. Thus, the high content of protein leads to increased water absorption capacity. Apart from that, Nuwamanya et al. (2010) reported that protein and carbohydrate content in cassava would influence water absorption capacity because both components have hydrophilic regions such as polar network and amino acid network. Hoover and Sosulski (1986) reported that the variation in water absorption capacity of starches could be due to the difference in the degree of the engagement of hydroxyl groups to form hydrogen and covalent bonds between starch chains.

\subsection{Swelling power}

Swelling power provides evidence of non-covalent bonding between starch molecules. Factors like amyloseamylopectin ratio, chain length and molecular weight distribution, degree/length of branching and conformation determine the degree of swelling and solubility (Rickard et al., 1991). Results for the swelling power of cassava starch are presented in Table 2 . Cassava starch from Semporna exhibits a high value of swelling power $(6.85 \%)$ compared to Tawau $(4.07 \%)$, and they are significantly different $(p<0.05)$. The results obtained in this study were slightly lower compared to previous findings. A study conducted by Charles et al. (2005) shows a swelling power value can be as high as $27.2 \%$ until $42.3 \%$, while another study conducted by Onitilo et al. (2007) shows a reading between 9.0\% until $16.9 \%$ for swelling power at temperature $80^{\circ} \mathrm{C}$. Delpeuch and Favier (1980) described that swelling volume also depend on the presence of various chemicals and treatments carried out on starch.

\subsection{Solubility}

The solubility values of the starch samples from 
Tawau and Semporna were $28.48 \%$ and $24.34 \%$, respectively. The solubility values of the samples were significantly different $(p<0.05)$. Past studies found that solubility properties of starch have an inversely proportional relationship with amylose content; meanwhile, swelling power also have an inversely proportional relationship with amylopectin content in cassava starch (Kruger et al., 2003). The data obtained in this study is in agreement with the findings by Kruger et al. (2003) in which an inversely proportional relationship occurs between amylose content and solubility of cassava starch from Tawau and Semporna. The same occurrence can be observed between amylopectin content with swelling power.

According to Aryee et al. (2006), low swelling power followed by high solubility properties of starch indicates weak associative forces in the starch granules. However, a weak associative force between starch granules is desired attribute in the processing of high glucose syrup since it favours the process of hydrolysis compared to starch that has high associative forces (Aryee et al., 2006). One of the factors that lead to weak associative power between starch granules is due to damage starch that occurs during its extraction. Amongst the factors that determine starch solubility are a source of starch, inter-associate forces, swelling power and presence of other components (Buckman et al., 2017).

\section{$3.8 \mathrm{pH}$}

The $\mathrm{pH}$ was observed to be lower for cassava starch isolated from Tawau (4.80) than for starch from Semporna (5.49) (Table 2). The $\mathrm{pH}$ values of the samples were significantly different $(p<0.05)$. The lower $\mathrm{pH}$ of cassava starch might be due to the presence of comparatively more impurities that incorporated into the starch during processing (Mishra and Rai, 2006). Sangeetha and Rai (2006) reported that the $\mathrm{pH}$ value of starch is influenced by two main factors that are the soil condition in the planted area as well as the compositional content of starch itself. Besides, the presence of foreign matter such as peel of cassava will as well influenced $\mathrm{pH}$ value in cassava starch (Mbougueng et al., 2008).

\subsection{Pasting properties}

The pasting properties of cassava starch are one of the factors to be considered to maximise the application of cassava starch in the food industry, mainly as a food thickener. The viscosity of paste formed after the heating process is a vital aspect to be studied to determine the type of instrument that suitable to be used during food processing (Zhu, 2015; Noorfarahzilah et al., 2017). Table 3 shows the pasting profiles of starch from two different locations. The results show that there were significant differences $(\mathrm{p}<0.05)$ for peak, trough, breakdown, and final viscosity, but there is no significant difference observed for setback viscosity. The peak viscosity obtained in this study is higher than reported by Colman et al. (2012). Peak viscosity indicates the waterbinding capacity of the starch or mixture. It is often correlated with final product quality. The peak viscosity occurs at the equilibrium point between swelling, causing an increase in viscosity and rupture and alignment, causing its decrease (Onitilo et al., 2007).

Table 3. Pasting properties of cassava starch

\begin{tabular}{lcc}
\hline \multicolumn{1}{c}{ Parameter } & Tawau & Semporna \\
\hline Peak viscosity $(\mathrm{cP})$ & $5575.33 \pm 209.00^{\mathrm{a}}$ & $5550.67 \pm 231.31^{\mathrm{a}}$ \\
Trough viscosity $(\mathrm{cP})$ & $1948.00 \pm 83.54^{\mathrm{a}}$ & $2039.33 \pm 55.19^{\mathrm{a}}$ \\
Breakdown viscosity $(\mathrm{cP})$ & $3627.33 \pm 127.45^{\mathrm{a}}$ & $3511.33 \pm 285.28^{\mathrm{a}}$ \\
Final viscosity (cP) & $2868.00 \pm 119.75^{\mathrm{a}}$ & $2799.33 \pm 102.79^{\mathrm{a}}$ \\
Setback viscosity $(\mathrm{cP})$ & $920.00 \pm 37.47^{\mathrm{a}}$ & $870.00 \pm 205.85^{\mathrm{b}}$ \\
Pasting temperature $\left({ }^{\circ} \mathrm{C}\right)$ & $72.98 \pm 0.53^{\mathrm{a}}$ & $72.67 \pm 0.06^{\mathrm{a}}$ \\
Peak time (min) & $4.98 \pm 0.12^{\mathrm{a}}$ & $3.07 \pm 0.04^{\mathrm{a}}$ \\
\hline
\end{tabular}

Values are expressed as mean \pm SD. Values with different superscript within the row are significantly different $(p<0.05)$.

The breakdown viscosity was $3627.33 \mathrm{cP}$ and $3511.33 \mathrm{cP}$ for starch from Tawau and Semporna, respectively. Adebowale et al. (2005) described that the higher the breakdown in viscosity, the lower the ability of the sample to withstand heating and shear stress during cooking. According to Sandhya Rani and Bhattacharya, (1995), the breakdown is caused by the disintegration of gelatinised starch granule structure during continued stirring and heating. The difference in breakdown viscosities is related to the difference in rigidity of swollen granules.

Results of the setback viscosity were $920.00 \mathrm{cP}$ and $870.00 \mathrm{cP}$ for starch from Tawau and Semporna, respectively. There is a significant difference $(p<0.05)$ in the setback viscosity of the starch samples. The values recorded are lower than the results obtained by Colman et al. (2002). The authors reported that the setback viscosity for native cassava starch was $948 \pm 6.93 \mathrm{cP}$. The pasting temperature of the starches obtained from Tawau $\left(72.98^{\circ} \mathrm{C}\right)$ and Semporna $\left(72.67^{\circ} \mathrm{C}\right)$ are within the range of the values previously reported for tuber (Charles et al., 2004; Abera and Rakshit, 2004; Charles et al., 2005). Pasting temperature represents the minimum temperature at which the sample will cook, which can have implications on the stability of other components in a formula and also indicate energy costs. In general, higher pasting temperature showed a higher degree of crystallinity of the starch (Mishra and Rai, 2006).

\subsection{Gelatinisation properties}

The gelatinisation properties of cassava starch are 
given in Table 4. There are no significant differences observed for onset, peak and final temperature, as well as enthalpy. A study conducted by Sandoval and Fernandez, (2013) show a higher result compared to the data obtained from this study in which the range for value $T_{o}, T_{p}$ and $T_{c}$ is falls between $60.9-66.51^{\circ} \mathrm{C}$, $65.44-72.00^{\circ} \mathrm{C}$ and $69.91-71.36^{\circ} \mathrm{C}$ respectively. Hashimoto and Grossmann (2003) reported that gelatinisation temperature is influenced by the surrounding temperature during the growing of cassava. Besides, Gerard et al. (2001) reported that a low value of $T_{o}, T_{p}$ and $T_{c}$ is due to the low amylopectin network in starch. Data obtained in this study supporting the idea of Gerard et al. (2001), where gelatinisation temperature of Tawau starch $T_{o}, T_{p}, T_{c}$ show high reading compared to Semporna in which both with $68^{\circ} \mathrm{C}, 72^{\circ} \mathrm{C}, 77^{\circ} \mathrm{C}$ and $62^{\circ}$ $\mathrm{C}, 71^{\circ} \mathrm{C}$ and $72^{\circ} \mathrm{C}$ respectively.

Table 4. Gelatinisation properties of cassava starch

\begin{tabular}{lcc}
\hline \multicolumn{1}{c}{ Parameter } & Tawau & Semporna \\
\hline Onset $\left({ }^{\circ} \mathrm{C}\right)$ & $68.93 \pm 0.21^{\mathrm{a}}$ & $62.59 \pm 1.08^{\mathrm{a}}$ \\
Peak $\left({ }^{\circ} \mathrm{C}\right)$ & $72.25 \pm 0.27^{\mathrm{a}}$ & $71.15 \pm 0.13^{\mathrm{a}}$ \\
End $\left({ }^{\circ} \mathrm{C}\right)$ & $77.30 \pm 0.44^{\mathrm{a}}$ & $73.53 \pm 0.69^{\mathrm{a}}$ \\
Entalphy $(\mathrm{J} / \mathrm{g})$ & $3.56 \pm 0.19^{\mathrm{a}}$ & $10.70 \pm 0.75^{\mathrm{a}}$ \\
\hline
\end{tabular}

Values are expressed as mean \pm SD. Values with different superscript within the row are significantly different $(p<0.05)$.

\subsection{Retrogradation properties}

Starch retrogradation is a process in which disaggregated amylose and amylopectin chains in a gelatinised starch paste re-associate to form more ordered structures (Wang et al., 2015). The retrogradation properties of cassava starch are presented in Table 5. Statistical analysis shows there is no significant difference $(\mathrm{p}>0.05)$ observed for all parameters, for both samples of starch. However, the $T p$ value obtained from this study $\left(55.54^{\circ} \mathrm{C}\right.$ and $\left.55.62^{\circ} \mathrm{C}\right)$ was higher compared to study conducted by Raphael et al. (2011) that is ranged from $51.01^{\circ} \mathrm{C}$ to $53.35^{\circ} \mathrm{C}$ whereas the enthalpy value in this study is lower $(0.40$ and $0.79 \mathrm{~J} / \mathrm{g}$ ) compared to study conducted by Raphael et al. (2011) that is ranged from 1.60 to $5.25 \mathrm{~J} / \mathrm{g}$. Moorthy (2002) reported that retrogradation for starch extracted from tubers is slower compared to starch extracted from cereals. A similar finding was reported by Yoo and Jane (2002). Lin et al. (2006) described that cassava starch contains more short-chain in amylopectin causes the retrogradation process to occur slower. Wang et al. (2015) reported that starch retrogradation is affected by several factors including water content, storage temperature, storage time, and additives (carbohydrates, salts, proteins, lipids and other food additives) in the system.
Table 5. Retrogradation properties of cassava starch

\begin{tabular}{lcc}
\hline \multicolumn{1}{c}{ Parameter } & Tawau & Semporna \\
\hline Onset $\left({ }^{\circ} \mathrm{C}\right)$ & $45.01 \pm 0.16^{\mathrm{a}}$ & $43.87 \pm 0.16^{\mathrm{a}}$ \\
Peak $\left({ }^{\circ} \mathrm{C}\right)$ & $55.54 \pm 0.59^{\mathrm{a}}$ & $55.62 \pm 0.41^{\mathrm{a}}$ \\
End $\left({ }^{\circ} \mathrm{C}\right)$ & $61.24 \pm 0.45^{\mathrm{a}}$ & $62.74 \pm 0.48^{\mathrm{a}}$ \\
Entalphy $(\mathrm{J} / \mathrm{g})$ & $0.40 \pm 0.02^{\mathrm{a}}$ & $0.79 \pm 0.03^{\mathrm{a}}$ \\
\hline
\end{tabular}

Values are expressed as mean \pm SD. Values with different superscript within the row are significantly different $(p<0.05)$.

\subsection{Starch granule morphology}

The morphology of cassava starch plays a vital role in its functional properties. By Scanning electron microscope (SEM), the starches isolated from Tawau and Semporna had smooth surfaces with some granules spherical, elongated and irregular in shape (Figure 1), with a diameter ranging between 2.81 and $21.8 \mu \mathrm{m}$, while those of Semporna ranged between 2.89 and 20.7 $\mu \mathrm{m}$. All the starch granules shape revealed by the SEM micrograph are as expected based on the previous study reported by Chandanasree et al. (2016) in which native starch granules are sphere, round and oval. However, several starch granules are concave in shape. Nuwamanya et al. (2010) reported that the starch granules that exist in concave shape are caused by excessive handling during its process of extraction from cassava. Differences in starch granules size may be attributed to the botanical origin as well as the variety of the crop.

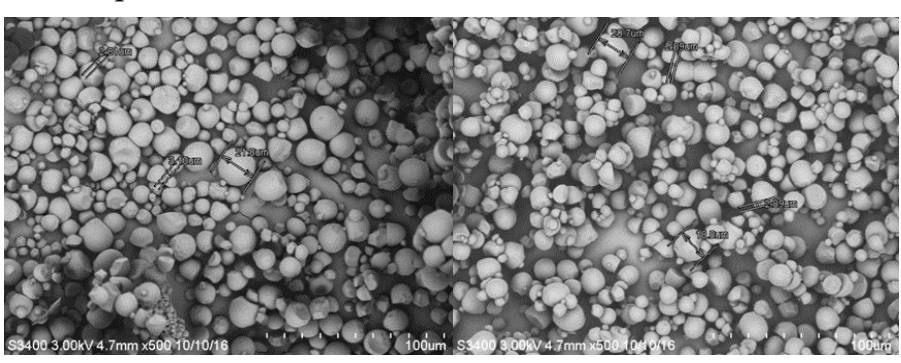

Figure 1. Granule morphology of cassava starch planted in Tawau (left) and Semporna (right) observed under scanning electron microscopy (SEM).

\section{Conclusion}

This study found that cassava starch extracted from different location varies in its properties. Starch isolated from Semporna showed a high amount of yield, total starch and amylose content compared to starch obtained from Tawau. A similar trend was also observed for swelling power, solubility and water absorption capacity. No significant difference observed for thermal profiles such as pasting, gelatinisation and retrogradation. Data obtained from this study could be used in food formulations as well as improving the functionality of cassava starch when used as a supplement ingredient in food production or to be used as biopolymer components in edible film preparations. 


\section{Conflict of interest}

The authors declare no conflicts of interest.

\section{Acknowledgement}

This present work was supported by Universiti Malaysia Sabah Research Grant (project number: SBK0234-STWN-2015).

\section{References}

Abdalla, A.A., Ahmed, U.M., Ahmed, A.R., Tinay, A.H. and Ibrahim, K.A. (2009). Physicochemical characterisation of traditionally extracted pearl millet starch. Journal of Applied Science, 5(11), 20162027.

Abera, S. and Rakshit, S.K. (2003). Comparison of physicochemical and functional properties of cassava starch extracted from fresh root and dry chips. Starch/Starke, 55(7), 287-296. https:// doi.org/10.1002/star.200390072

Adebowale, Y.A., Adeyemi, I.A. and Oshodi, A.A. (2005). Functional and physic-chemical properties of six Mucuna species. African Journal of Biotechnology, 4(12), 1461-1468.

Aniedu, C. and Omodamiro, R.M. (2012). Use of newly bred $\beta$-carotene cassava in production of value added products: Implication for food security in Nigeria. Global Journal of Science Frontier Research Agriculture and Veterinary Sciences, 12(10), 11-16.

AOAC. (2000). Official Methods of Analysis of AOAC International. $17^{\text {th }}$ edition. USA: AOAC International, Md.

Asoaka, M., Blanshard, J.M.V and Rickard, J.E. (1991). Seasonal effects on the physico-chemical properties of starch from four cultivars of cassava. Starch/ Stärke, 43, 455-459. https://doi.org/10.1002/ star. 19910431202

Aprianita, A., Vasiljevic, T., Bannikova, A. and Kasapis, S. (2014). Physicochemical properties of flours and starches derived from traditional Indonesian tubers and roots. Journal of Food Science and Technology, 51(12), 3669-3679. https://doi.org/10.1007/s13197012-0915-5

Aryee, F.N.A., Oduro, I., Ellis, W.O. and Afuakwa, J.J. (2005). The physicochemical properties of flour samples from the roots of 31 varieties of cassava. Food Control, 17(11), 916-922. https:// doi.org/10.1016/j.foodcont.2005.06.013

Ashwar, B.A., Gani, A., Shah, A., Wani, I.A. and Masoodi, F.A. (2015). Preparation, health benefits and applications of resistant starch-a review. Starch/ Stärke, 68(3-4), 287-301. https://doi.org/10.1002/ star.201500064

Blazek, J. and Copeland, L. (2008). Pasting and swelling properties of wheat flour and starch in relation to amylose content. Carbohydrate Polymers, 71(3), 380 -387. https://doi.org/10.1016/j.carbpol.2007.06.010

Breuninger, W.F., Piyachomkwan, K. and Sriroth, K. (2009). Tapioca/cassava starch: Production and use. In BeMiller, J. and Whistler, R. (Eds.). Starch Chemistry and Technology, p. 544. New York, USA: Academic Press. https://doi.org/10.1016/B978-0-12746275-2.00012-4

Buckman, E.S., Oduro, I., Plahar, W.A. and Tortoe, C. (2017). Determination of the chemical and functional properties of yam bean (Pachyrhizus erosus (L.) Urban) flour for food systems. Food Science and Nutrition, 6(2), 457-463. https://doi.org/10.1002/ fsn3.574

Buléon, A., Colonna, P., Planchot, V. and Ball, S. (1998). Starch granules: structure and biosynthesis. International Journal of Biological Macromolecules, 23(2), 85-112. https://doi.org/10.1016/S0141-8130 (98)00040-3

Buttriss, J.L. and Stokes, K. (2008). Dietary fibre and health: An overview. Nutrition Bulletin, 33(3), 186200. https://doi.org/10.1111/j.14673010.2008.00705.x

Chandanasree, D., Gul, K. and Riar, C.S. (2016). Effect of hydrocolloids and sry heat modification on physicochemical, thermal, pasting and morphological characteristics of cassava (Manihot esculenta) starch. Food Hydrocolloids, 52, 175-182. https://doi.org/10.1016/j.foodhyd.2015.06.024

Charles, A.L., Chang, Y.H., Ko, W.C., Sriroth, K. and Huang, T.C. (2004). Some physical and chemical properties of starch isolates of cassava genotypes. Starch/Stärke, 56(9), 413-418. https:// doi.org/10.1002/star.200300226

Charles, A.L., Chang, Y.H., Ko, W.C., Sriroth, K. and Huang, T.C. (2005). Influence of amylopectin structure and amylose content on the gelling properties of five cultivars of cassava starches. Journal of Agricultural and Food Chemistry, 53, 2717-2725. https://doi.org/10.1021/jf048376+

Colman, T.A.D., Demiate, I.M. and Schnitzler, E. (2012). The effect of microwave radiation on some thermal, rheological and structural properties of cassava starch. Journal of Thermal Analysis and Calorimetry, 115(3), 2245-2252. https:// doi.org/10.1007/s10973-012-2866-5

Delpeuch, F. and Favier, J.C. (1980). Characteristics of starches from tropical food plants; $\alpha$-amylase hydrolysis, swelling and solubility patterns. Annals 
of Agricultural Sciences, 29, 53-67.

Eriksson, E. (2013). Flour from three local varieties of cassava (Manihot esculenta Crantz): physicochemical properties, bread making quality and sensory evaluation. Uppsala: Swedish University of Agricultural Science.

French, D. (1984). In Whistle, R.L., Bemiller, J.N. and Paschall, E.F. (Eds.). Starch, Chemistry and Technology, p. 183-247. New York: Academic Press.

Gerard, C., Barron, C., Colonna, P. and Planchot, V. (2001). Amylose determination in genetically modified starches. Carbohydrate Polymers, 44(1), 10-27. https://doi.org/10.1016/S0144-8617(00)00194 $-6$

Hashimoto, J.M. and Grossmann, M.V.E. (2003). Effects of extrusion conditions on quality of cassava bran/ cassava starch extrudates. International Journal of Food Science and Technology, 38(5), 511-517. https://doi.org/10.1046/j.1365-2621.2003.00700.x

Hasmadi, M., Noorfarahzilah, M., Noraidah, H., Zainol, M.K. and Jahurul, M.H.A. (2020). Functional properties of composite flour: a review. Food Research, 4(6), 1820-1831. https://doi.org/10.26656/ fr.2017.4(6).419

Hoover, R. and Sosulski, F. (1986). Effect of cross linking on functional properties of legume starches. Starch/Starke, 38(5), 149-155. https:// doi.org/10.1002/star.19860380502

Ikegwu, O.J., Okechukwu, P.E. and Ekumankana, E.O. (2010). Physico-Chemical and pasting characteristics of flour and starch from Achi Brachystegia eurycoma seed. Journal of Food Technology, 8(2), 58-66. https://doi.org/10.3923/jftech.2010.58.66

Joseph, R., Yeoh, H.H. and Loh, C.S. (2004). Induced mutations in cassava using somatic embryos and the identification of mutant plants with altered starch yield and composition. Plant Cell Reports, 23, 9198. https://doi.org/10.1007/s00299-004-0798-7

Kruger, A., Ferrero, C. and Zaritzky, N.E. (2003). Modeling corn starch swelling in batch systems: effect of sucrose and hydrocolloids. Journal of Food Engineering, 58(2), 125-133. https:// doi.org/10.1016/S0260-8774(02)00337-0

Li, J.-Y. and Yeh, A.-L. (2001). Relationship between thermal, rheological characteristics and swelling power for various starches. Journal of Food Engineering, 50(3), 141-148. https:// doi.org/10.1016/S0260-8774(00)00236-3

Lin, H.M., Chang, Y., Lin, J., Jane, J., Sheu, M. and Lu, T. (2006). Heterogeneity of lotus rhizome starch granules as revealed by alpha-amylase degradation.
Carbohydrate Polymers, 66(4), 528-536. https:// doi.org/10.1016/j.carbpol.2006.04.024

Mamat, H., Abu-Hardan, M.O. and Hill, S.E. (2010). Physicochemical properties of commercial semisweet biscuit. Food Chemistry, 121(4), 1029-1038. https://doi.org/10.1016/j.foodchem.2010.01.043

Mamat, H. and Hill, S.E. (2018). Structural and functional properties of major ingredients of biscuit. International Food Research Journal, 25(2), 467471.

Martín Bernabé, A., Srikaeo, K. and Schlüter, M. (2011). Resistant starch content, starch digestibility and the fermentation of some tropical starches in vitro. Food Digestion, 2(1-3), 37-42. https://doi.org/10.1007/ s13228-011-0013-6

Mbougueng, P.D., Tenin, D., Scher, J. and Tchiengang, C. (2008). Physicochemical and functional properties of some cultivar of Irish potato and cassava starches. Journal of Food Technology, 6(3), 139-146.

Mishra, S and Rai, T. (2006). Morphology and functional properties of corn, potato and tapioca starches. Food Hydrocolloids, 20(5), 557-566. https:// doi.org/10.1016/j.foodhyd.2005.01.001

Moorthy, S.N. (2002). Physicochemical and functional properties of tropical tuber starches. Starch/Starke, 54(12), 559-592. https://doi.org/10.1002/1521-379X (200212)54:12<559::AID-STAR2222559>3.0.CO;2$\mathrm{F}$

Mustapha, S., Mohammed, U.M., Adeosun, N.O., Mathew, T.J., Muhammed, S.S. and Ibn-Aliyu, A. (2015). Nutritional and functional characterisation of undecorticated groundnut (Arachis hypogaea L.) seeds from Bosso Market, Minna, Nigeria. American Journal of Food Science and Technology, 3(5), 126131.

Niba, L.L., Bokanga, M.M., Jackson, E.L., Schlimme, D.S. and Li, B.W. (2002). Physicochemical properties and starch granular characteristics of flour from various Manihot Esculenta (cassava) genotypes. Journal of Food Science, 67(5), 1707$1705 . \quad$ https://doi.org/10.1111/j.13652621.2002.tb08709.x

Niba, L.L. and Hoffman, J. (2003). Resistant starch and a -glucan levels in grain sorghum (Sorghum bicolor M.) and influenced of soaking and autoclaving. Food Chemistry, 81(1), 13-118. https://doi.org/10.1016/ S0308-8146(02)00386-2

Noorfarahzilah, M., Mansoor, A.H. and Mamat, H. (2017). Proximate composition, mineral content and functional properties of tarap (Artocarpus odoratissimus) seed flour. Food Research, 1(3), 8996. https://doi.org/10.26656/fr.2017.3.025 
Noorfarahzilah, M., Jau-Shya, L., Mansoor, A.H., Jahurul, M.H.A., Umi Hartina, M.R., Zainol, M.K. and Hasmadi, M. (2020). Physicochemical properties of tarap (Artocarpus adoratisimus) starch. Food Research, 4(3), 602-611. https://doi.org/10.26656/ fr.2017.4(3).337

Nuwamanya, E., Baguma, Y., Emmambux, N., Taylor, J. and Patrick, R. (2010). Physicochemical and functional characteristics of cassava starch in Ugandan varieties and their progenies. Journal of Plant Breeding and Crop Science, 2(1), 1-11.

Olomo, V. and Ajibola, O. (2003). Processing factors affecting the yield and physicochemical properties of starch from cassava chips and flour. Starch/Stärke, 55(10), 476-481. https://doi.org/10.1002/ star.200300201

Onitilo, M.O., Sanni, L.O., Daniel, I., Maziya-Dixon, B. and Dixon, A. (2007). Physicochemical and functional properties of native starches from cassava varieties in Southwest Nigeria. Journal of Food, Agriculture and Environment, 5(3), 108-114.

Raphael, M., Yona, B., Stephen, K., Ephraim, N., Patrick, R., Settumba, M., Bruce, H. and Samuel, K. (2011). Amylopectin molecular structure and functional properties of starch from three Uganda cassava varieties. Journal of Plant Breeding and Crop Science, 3(9), 195-202.

Rickard, J.E., Asaoka, M.J. and Blanshard, M.V. (1991). The physicochemical properties of cassava starch. Tropical Science, 31, 189-207.

Rodríguez-Sandoval, E., Fernández-Quintero, A., Cuvelier, G., Relkin, P. and Bello-Pérez, L. (2008). Starch retrogradation in cassava flour from cooked parenchyma. Starch/Stärke, 60(3-4), 174-180. https://doi.org/10.1002/star.200700683

Sajilata, M.G., Singhal, R.S. and Kulkarni, P.R. (2006). Resistant starch; A review. Comprehensive Reviews in Food Science and Food Safety, 5(1), 1-17. https:// doi.org/10.1111/j.1541-4337.2006.tb00076.x

Sandhya Rani, M.R. and Bhattacharya, K.R. (1995). Microscopy of rice starch granules during cooking. Starch/Starke, 47(9), 334-337. https:// doi.org/10.1002/star.19950470903

Sandoval, A. and Fernández, Q. (2013). Physicochemical characterization of two cassava (Manihot esculenta Crantz) starches and flours. Scientia Agroalimentaria, 1, 19-25.

Sangeetha, M. and Rai, T. (2006). Morphology and functional properties of corn, potato and tapioca starches. Food Hydrocolloids, 20(5), 557-566. https://doi.org/10.1016/j.foodhyd.2005.01.001

Tanukari, N.J. (2004). Cassava and the future of starch.
Journal of Biotechnology, 7(1), 5-8. https:// doi.org/10.2225/vol7-issue1-fulltext-9

Tester, R.F. (1997). Starch: The Polysaccharide Fractions. In Frazier, P.J., Richmond P. and Donald, A.M. (Eds.). Starch: Structure and Functionality, p. 163-171. Royal Society of Chemistry: Cambridge.

Tukomane, T., Leerapongnun, P., Shobsngob, S. and Varavinit, S. (2007). Preparation and characterisation of annealed- enzymatically hydrolysed tapioca starch and the utilisation in tableting. Starch/Stärke, 59(1), 33-45. https:// doi.org/10.1002/star.200600524

Wang, S., Li, C., Copeland, L., Niu, Q. and Wang, S. (2015). Starch retrogradation: A comprehensive review. Comprehensive Reviews in Food Science and Food Safety, 14(5), 568-585. https:// doi.org/10.1111/1541-4337.12143

Yoo, S. and Jane, J. (2002). Structural and physical characteristics of waxy and other wheat starches. Carbohydrate Polymers, 49(3), 297-305. https:// doi.org/10.1016/S0144-8617(01)00338-1

Zhu, F. (2015). A review on composition, structure, physicochemical properties, and modifications of cassava starch. Carbohydrate Polymers, 122, 456480. https://doi.org/10.1016/j.carbpol.2014.10.063 